\title{
The rate of chemical weathering beneath a quiescent, surge-type, polythermal-based glacier, southern Spitsbergen, Svalbard
}

\author{
J. L. Wadham, ${ }^{1}$ A. J. Hodson, ${ }^{2}$ M. Tranter, ${ }^{1}$ J. A. Dowdeswell ${ }^{3}$ \\ ${ }^{1}$ Department of Geography, University of Bristol, Bristol BS8 1SS, England \\ ${ }^{2}$ Department of Geography, University of Oxford, Oxford OX13TB, England \\ ${ }^{3}$ Centre for Glaciology, Institute of Earth Studies, University of Wales, Aberystwyth SY23 3DB, Wales
}

\begin{abstract}
Glacierized basins in the high Arctic are believed to be regions of low chemical weathering rates, despite the lack of pertinent data, because it is believed that water does not flow in significant quantities through subglacial drainage systems. We have calculated chemical weathering rates at Finsterwalderbreen, a polythermal, surge-type glacier in Svalbard. Rates of 320 and $150 \mathrm{meq} \sum^{+} \mathrm{m}^{-2}$ year $^{-1}$ were measured in 1994 and 1995 , respectively. The corresponding water fluxes were $4.1 \times 10^{7}$ and $1.7 \times 10^{7} \mathrm{~m}^{3}$. We estimate that we have measured $\sim 72 \%$ of the total annual discharge, hence the true annual chemical weathering rates are $\sim 440$ and $210 \mathrm{meq} \sum^{+} \mathrm{m}^{-2}$ year $^{-}$, respectively. This gives a mean annual chemical weathering rate of $330 \mathrm{meq} \sum^{+} \mathrm{m}^{-2}$ year ${ }^{-1}$, which approximates the continental average of 390 meq $\sum^{+} \mathrm{m}^{-2}$ year ${ }^{-1}$ and is intermediate between chemical weathering rates measured on cold-based glaciers $\left(\sim 110-160 \mathrm{meq} \sum^{+} \mathrm{m}^{-2}\right.$ year $\left.{ }^{-1}\right)$ and temperate glaciers $\left(450-1000 \mathrm{meq} \sum^{+} \mathrm{m}^{-2}\right.$ year $\left.^{-1}\right)$. This suggests that there may be a direct link between chemical weathering rates and thermal regime, and that glacierized basins in the high Arctic cannot necessarily be considered as regions of low chemical weathering and $\mathrm{CO}_{2}$ drawdown.
\end{abstract}

\section{INTRODUCTION}

Glacial environments are often considered as areas of low chemical weathering rates, due to low temperatures and minimal biological activity (Kump and Alley, 1994). This conviction has been used to justify assumptions of minimal chemical weathering beneath ice (Gibbs and Kump, 1994; Kump and Alley, 1994). Recent empirical, hydrochemical work shows temperate glaciers to be characterised by elevated chemical weathering rates, as much as $1.2-2.6$ times the continental average (Souchez and Lemmens, 1987). The supply of large volumes of dilute meltwaters to highly reactive, freshly comminuted, glacial rock flour and other glacial debris facilitates rapid rates of hydrolytic weathering of carbonate and aluminosilicate rocks. These reactions usually require a supply of protons. This condition is partly satisfied by carbonation reactions, involving the dissociation of carbonic acid derived from the dissolution of $\mathrm{CO}_{2}$ in water. Consumption of protons increases the $\mathrm{pH}$ of a solution, leading to a reduction in $p \mathrm{CO}_{2}$ and consequent diffusion of $\mathrm{CO}_{2}$ into solution. This may take place wherever waters come into contact with the atmosphere via open conduits or air bubbles in the ice. Thus, chemical weathering also provides a mechanism whereby $\mathrm{CO}_{2}$ is drawn down from the atmosphere with increasing demand for protons (Sharp and others, 1995).

Current assessments of glacial chemical weathering rates are derived from temperate glaciers, where meltwater has considerable contact with basal rock material via a welldeveloped subglacial drainage system (Sharp and others, 1995). Chemical weathering beneath high-Arctic glaciers, however, has received comparatively little attention. A predominance of cold basal ice on these glaciers is held to restrict the access of meltwaters to the bed (Sugden and John, 1976), leading to low overall chemical weathering rates. Support for this argument derives from the only two chemical weathering rates measured on high-Arctic glaciers, of $160 \mathrm{meq} \sum^{+} \mathrm{m}^{-2}$ year $^{-1}$ at Scott Turnerbreen in central Spitsbergen (Hodgkins and others, in press) and $\sim 110 \mathrm{meq} \sum^{+} \mathrm{m}^{-2}$ year ${ }^{-1}$ at Austre Brøggerbreen, Svalbard (A.J. Hodson, unpublished data), where meltwater contact with glacial debris is restricted to supraglacial and ice-marginal environments.

Most glaciers on Svalbard are polythermal (Dowdeswell and others, 1984) with at least part of their basal ice at the pressure-melting point (Schytt, 1969). Chemical weathering rates in these glacial systems have yet to be evaluated. Here, we address this shortcoming through an investigation of runoff and hydrochemistry at Finsterwalderbreen, a polythermal glacier in southern Spitsbergen.

\section{STUDY AREA AND METHODS}

Finsterwalderbreen $\left(77^{\circ} 28^{\prime} \mathrm{N}, 15^{\circ} 18^{\prime} \mathrm{E}\right)$ has a catchment area of $68 \mathrm{~km}^{2}$, of which $44 \mathrm{~km}^{2}$ is glaciated (including $9 \mathrm{~km}^{2}$ of dead ice) (see Fig. 1). The glacier is $11 \mathrm{~km}$ long and has a polythermal regime, being mainly warm-based except beneath the thinner ice at the front and lateral margins (Ødegård and others, 1997). The equilibrium line is located in a zone around $500 \mathrm{~m}$ a.s.l. (personal communication from J. F. Pinglot and others, 1996). The glacier is reported to have surged some time between 1898 and 1910, during which its lower half 
increased in thickness (Nuttall and others, 1997). The bedrock geology is mainly of sedimentary origin, consisting of Precambrian carbonates, phyllite and quartzite, and Permian sandstones, dolomites and limestones in the upper catchment, and Triassic to Cretaceous siltstones, sandstones and shales at lower elevations (Dallmann and others, 1990).

Fieldwork was conducted during the 1994 and 1995 melt seasons from 24 June to 19 August (Julian days 176-231) and 25 June to 14 August (Julian days 176-227), respectively. About $90 \%$ of the glacier's meltwater drains from two outflows on the western margin: a basal conduit and a subterranean upwelling of water about $10 \mathrm{~m}$ to the east of the basal conduit (Fig. 1). These two outflows converge $10 \mathrm{~m}$ downstream and together constitute the bulk meltwaters. A gauging station was established approximately $10-40 \mathrm{~m}$ downstream from the confluence. Frequent channel migration, high flows and icebergs periodically destroyed the gauging station, which was subsequently repositioned at the nearest convenient site. Bulk meltwater stage was measured continuously by a Druck pressure transducer, and hourly averages of 10 s readings were logged by a CR10 data logger. Stage was calibrated to discharge daily by manual gauging when possible, using the velocity/area method (Tranter and others, 1996). Diurnal variations in discharge were considered insufficient to warrant more frequent calibrations. Errors in discharge data are $\sim 15 \%$.

A single bulk meltwater sample was collected daily between 1500 and $1900 \mathrm{~h}$ throughout both the 1994 and 1995 melt seasons. Samples were filtered immediately and stored in plastic bottles. The samples were analyzed for $\mathrm{pH}$ using a portable Orion 290A pH meter and Orion $\mathrm{pH}$ electrode up to a few days after storage. $\mathrm{Cl}^{-}, \mathrm{SO}_{4}{ }^{2-}$ and $\mathrm{Ca}^{2+}$ were determined by ion chromatography on a Dionex 4000 i some 2-9 months after collection. Alkalinity (predominantly $\mathrm{HCO}_{3}{ }^{-}$) was determined by colorimetric titration up to 2 months after collection. The precision of these determinations is $\pm 4 \%$ and $\pm 0.6 \%$, respectively. The mean charge balance error for bulk meltwaters was $-2.7 \%$.

During spring 1995, 60 snow samples were collected from six pits located along the glacier centre line, so that bulk meltwater solute concentrations could be corrected for snowpack input. Within $24 \mathrm{~h}$ of collection, snow samples were melted, filtered and stored at room temperature for 2 weeks -4 months. Chemical analysis was carried out as above.

\section{RESULTS}

Concentrations of $\mathrm{Ca}^{2+}$ were corrected for the sea-salt-derived contribution from the snowpack by using the ionic ratio of $\mathrm{Cl}^{-}: \mathrm{Ca}^{2+}$ in sea water (Holland, 1978) and the $\mathrm{Cl}^{-}$ content of bulk runoff (assumed to be derived entirely from sea salt). $\mathrm{SO}_{4}{ }^{2-}$ concentrations in the bulk runoff were also corrected for the snowpack input (i.e. that associated with sea salt and with other $\mathrm{SO}_{4}{ }^{2-}$ containing aerosols) using the mean ratio of $\mathrm{Cl}^{-}: \mathrm{SO}_{4}{ }^{2-}$ in snow samples. Non-sea-salt $\mathrm{Ca}^{2+}$ and non-snowpack $\mathrm{SO}_{4}{ }^{2-}$ are denoted as "*".

Discharge time series for both the 1994 and 1995 field seasons are given in Figure 2a. Both seasons exhibit mid-season peak flows, with periods of recession during the early and late season, when discharges were $<6 \mathrm{~m}^{3} \mathrm{~s}^{-1}$ in 1994 and $<2 \mathrm{~m}^{3} \mathrm{~s}^{-1}$ in 1995. High flows towards the end of 1995 (JD 224) are probably associated with accelerated ablation and rapid transit of meltwater through an efficient, well-developed,
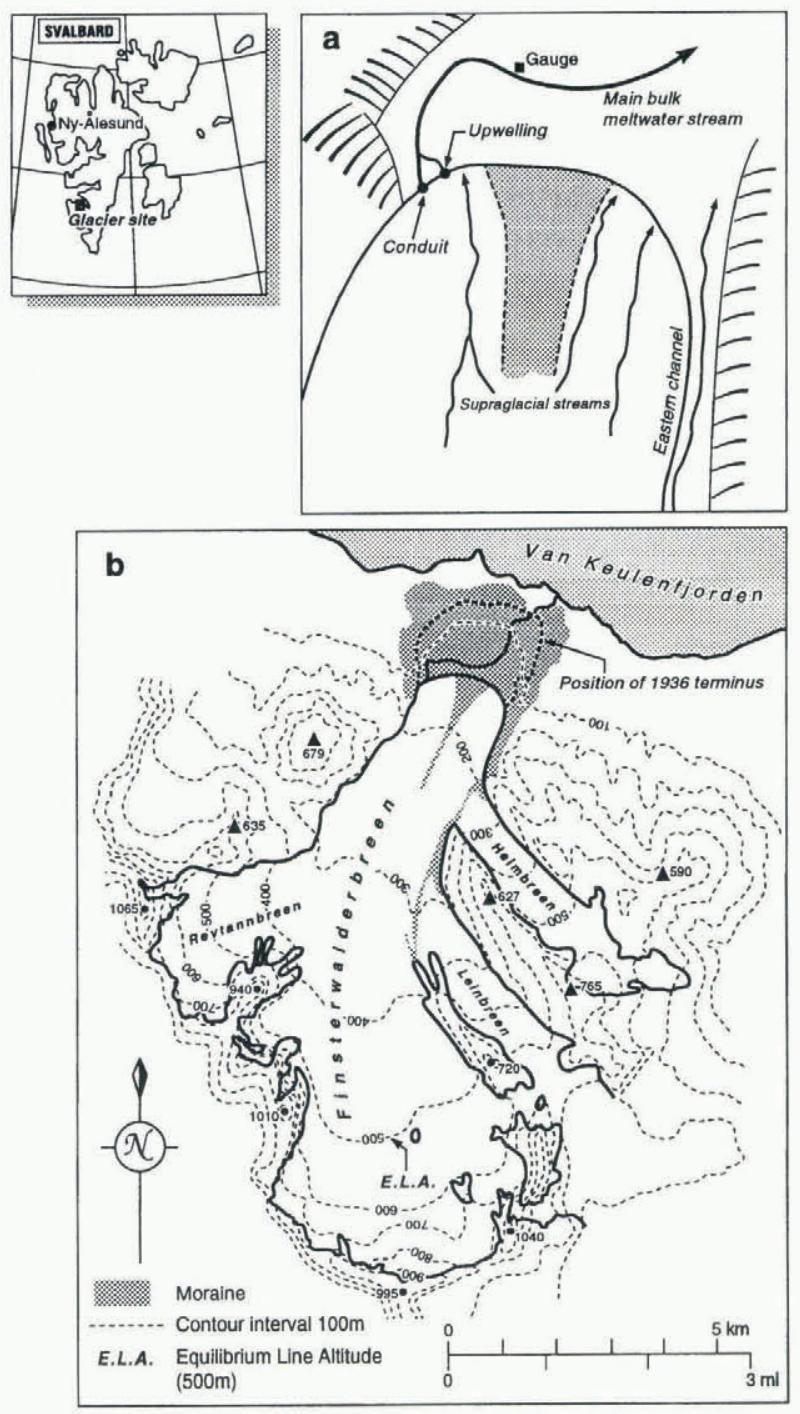

Fig. 1. (a) Sketch map of glacier snout. (b) Map of Finsterwalderbreen, Svalbard.

channelised drainage system. The peak discharge is up to three times greater during 1994 than 1995 due to high rainfall, attaining values of $35 \mathrm{~m}^{3} \mathrm{~s}^{-1} \cdot \mathrm{HCO}_{3}{ }^{-}$loads replicate the main trends in discharge, with the highest $\mathrm{HCO}_{3}{ }^{-}$loads registered during peak flows (Fig. 2b). ${ }^{*} \mathrm{SO}_{4}{ }^{2-}$ and ${ }^{*} \mathrm{Ca}^{2+}$ loads also display similar trends, although these data are not presented here.

Rates of chemical weathering were calculated in the following manner. The errors in flux determinations, estimated to be $\sim \pm 25 \%$, are similar in magnitude to those in previous chemical weathering studies. Solute fluxes have not been corrected for rainfall inputs of non-sea-salt aerosol, which are considered to be relatively trivial. The annual water flux for 1994 and 1995 was determined by calculating the flux of water per hour, and summing the values for the whole season. Missing discharge values were interpolated, or predicted from the association between electrical conductivity and discharge for the preceding and following periods. The cumulative water flux for the season was multiplied by the summed discharge-weighted mean concentration of $\mathrm{HCO}_{3}{ }^{-}$and ${ }^{*} \mathrm{SO}_{4}{ }^{2-}$ (assumed to be equal to the cation concentration by charge balance). This value was then divided by the catchment area $\left(68 \mathrm{~km}^{2}\right)$ to give the rate of chemical weathering over the sampling season in meq $\sum^{+} \mathrm{m}^{-2}$. We estimate that $\sim 80 \%$ of the annual bulk 

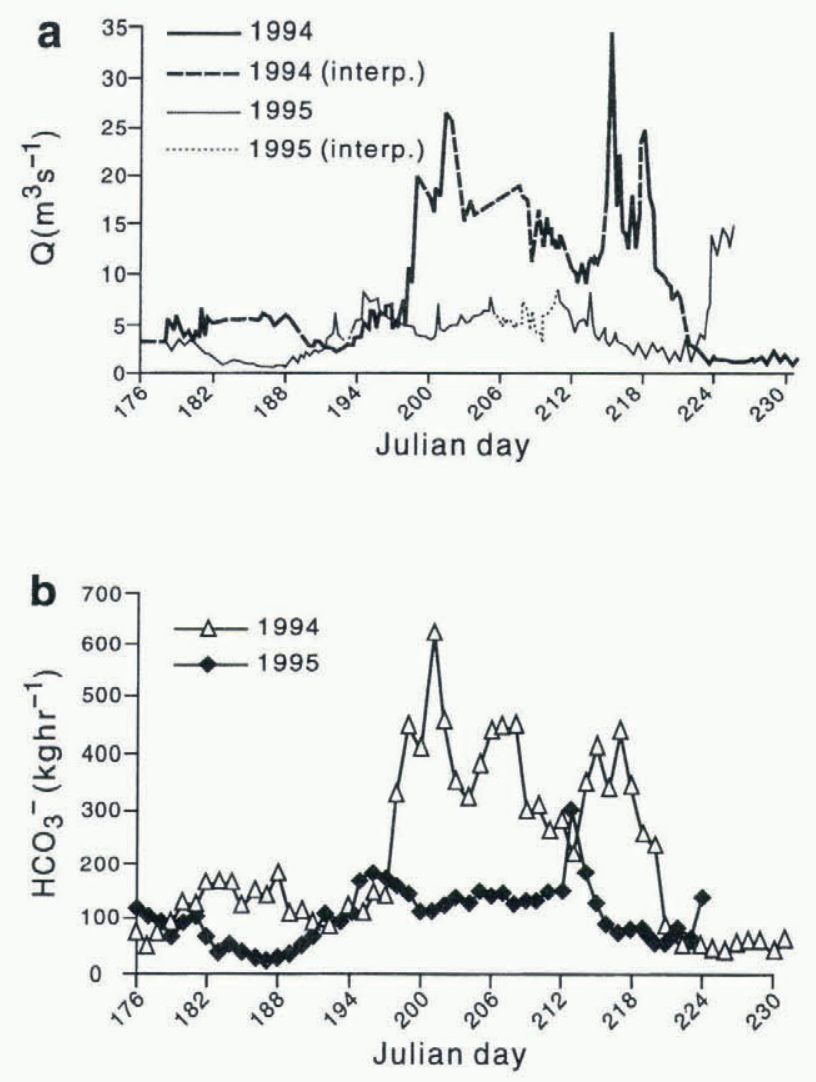

Fig. 2. Temporal variation in (a) bulk runoff $(Q)$ and $(b)$ $\mathrm{HCO}_{3}{ }^{-}$loads during 1994 and 1995 at Finsterwalderbreen. Julian days 176-231.

runoff was discharged during the sampling season (after Repp, 1988). Given that our gauging site collects $\sim 90 \%$ of the drainage from the catchment, the total water flux measured is $\sim 72 \%$ of the annual flux. Rates of measured chemical weathering and water fluxes are given in Table 1 , as are our estimated annual rates.

The concentrations of crustal ions $\left(\mathrm{HCO}_{3}{ }^{-},{ }^{*} \mathrm{SO}_{4}{ }^{2-}\right.$ and ${ }^{*} \mathrm{Ca}^{2+}$ ) in bulk meltwater samples show inverse relationships with discharge (Fig. 3a). Both ${ }^{*} \mathrm{SO}_{4}{ }^{2}$ and $\mathrm{HCO}_{3}{ }^{-}$display high concentrations at low discharge $\left(>700 \mu \mathrm{eq}^{-1}\right)$, but while ${ }^{*} \mathrm{SO}_{4}{ }^{2-}$ declines steeply as discharge rises, the corresponding decrease in $\mathrm{HCO}_{3}{ }^{-}$is less and concentrations of $>400 \mu \mathrm{eq}^{-1}$ are maintained. The association of ${ }^{*} \mathrm{Ca}^{2+}$ (as the major cation) with discharge represents the summation of both these trends.

We have estimated the minimum $\mathrm{CO}_{2}$ drawdown from instantaneous $\mathrm{HCO}_{3}{ }^{-}$loads, averaged over an hour, as fol-

Table 1. Water fluxes and chemical weathering rates at Finsterwalderbreen lows. Of the total $\mathrm{HCO}_{3}{ }^{-}$, some is assumed to be derived from coupled sulphide oxidation/carbonate dissolution:

coupled sulphide oxidation/carbonate dissolution

$$
\begin{gathered}
4 \mathrm{FeS}_{2}(\mathrm{aq})+16 \mathrm{CaCO}_{3}(\mathrm{~s})+15 \mathrm{O}_{2}(\mathrm{~g})+14 \mathrm{H}_{2} \mathrm{O}(\mathrm{aq}) \\
\leftrightarrow \\
16 \mathrm{Ca}^{2+}(\mathrm{aq})+16 \mathrm{HCO}_{3}^{-}(\mathrm{aq})+8 \mathrm{SO}_{4}{ }^{2-}(\mathrm{aq})+4 \mathrm{Fe}(\mathrm{OH})_{3}(\mathrm{~s}) .
\end{gathered}
$$

Hence, two moles of $\mathrm{HCO}_{3}{ }^{-}$for each mole of $\mathrm{SO}_{4}{ }^{2-}$ are subtracted from the total concentration of $\mathrm{HCO}_{3}{ }^{-}$. Of the remaining $\mathrm{HCO}_{3}{ }^{-}$, half is assumed to come from the atmosphere and half from carbonate rocks:

carbonation of carbonates

$\mathrm{CaCO}_{3}(\mathrm{~s})+\mathrm{H}_{2} \mathrm{O}(\mathrm{aq})+\mathrm{CO}_{2}(\mathrm{aq}) \leftrightarrow \mathrm{Ca}^{2+}(\mathrm{aq})+2 \mathrm{HCO}_{3}^{-}(\mathrm{aq})$.

We have also applied a minor correction for $\mathrm{HCO}_{3}{ }^{-}$acquired by the neutralisation of snowpack acidity. These calculations give a minimum estimate of $\mathrm{CO}_{2}$ drawdown, as they do not take account of $\mathrm{HCO}_{3}{ }^{-}$derived from the carbonation of aluminosilicate and silicate minerals.

$\mathrm{CO}_{2}$ drawdown at Finsterwalderbreen ranges from 1 to $150 \mathrm{~kg} \mathrm{Ch}^{-1}$ and exhibits a strong direct association with bulk discharge $\left(1.5 \mathrm{~g} \mathrm{C} \mathrm{m}^{-3}, R^{2}=0.96\right)$ (Fig. 3b). This compares with a rate of $1.2 \mathrm{~g} \mathrm{Cm}^{-3}$ drawdown at Haut Glacier d'Arolla, Switzerland (Sharp and others, 1995).

\section{DISGUSSION: RATES OF CHEMICAL WEATHER- ING AND $\mathrm{CO}_{2}$ DRAWDOWN}

Calculated chemical weathering rates of 440 and
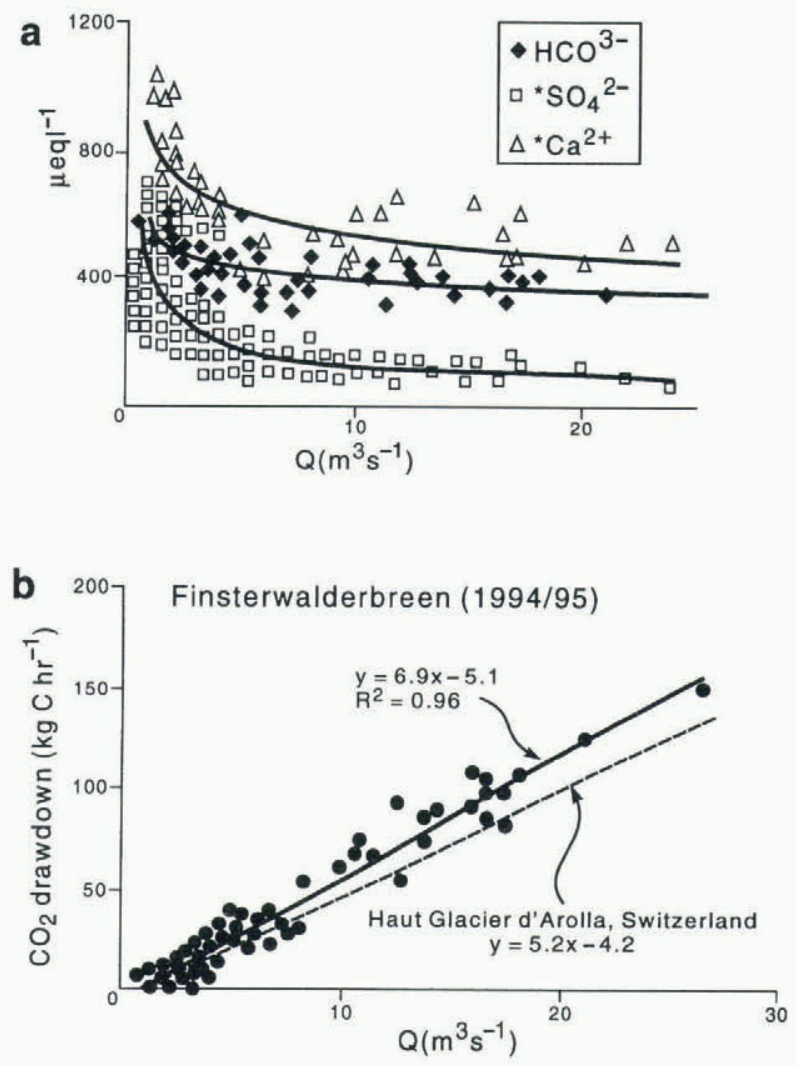

Fig. 3. (a) Association between $\mathrm{HCO}_{3}{ }^{-},{ }^{*} \mathrm{SO}_{4}{ }^{2}$ and $\mathrm{Ca}^{2+}$ and bulk discharge in 1994. $\mathrm{HCO}_{3}{ }^{-}$data for 1995 are also included. (b) Association between bulk discharge and $\mathrm{CO}_{2}$ drawdown in 1994 and 1995. 
210 meq $\sum^{+} \mathrm{m}^{-2}$ year $^{-1}$ in 1994 and 1995, respectively, (see Table 1) give a mean annual weathering rate of 330 meq $\sum^{+} \mathrm{m}^{-2}$ year ${ }^{-1}$. These rates are considerably higher than rates of $\sim 110-160 \mathrm{meq} \sum^{+} \mathrm{m}^{-2}$ year ${ }^{-1}$ measured at predominantly cold-based glaciers (Hodgkins and others, in press; A. J. Hodson, unpublished data), and approach chemical weathering rates on temperate glaciers that range from 450 to 1000 meq $\sum^{+} \mathrm{m}^{-2}$ year $^{-1}$ (see Fig. 4). Inter-glacier comparisons of chemical weathering rates, however, are complicated by a number of factors. There may be error in some of the former estimates due to the failure to distinguish between crustal and atmospherically derived solute (Sharp and others, 1995). Varying degrees of glacierization of the catchment area, together with differing relative proportions of active and stagnant ice, may also influence the magnitude of calculated chemical weathering rates. For example, chemical weathering rates at Finsterwalderbreen are considerably deflated because only half of the catchment is occupied by active glacier ice. We also appreciate that differences in lithology confound a simple, direct comparison between basins. Since an appreciable quantity of reactive carbonate minerals exists in the upper catchment of Finsterwalderbreen, the chemical weathering rates we calculate may be higher than for basins that do not contain carbonate rocks. Chemical weathering rates at Finsterwalderbreen, however, are $2-3$ times the magnitude of those calculated for Broggerbreen, Svalbard (A.J. Hodson, unpublished data), a predominantly coldbased catchment of similar lithology. This points towards thermal regime as a first-order control on chemical weathering rates. Extrapolation of our findings to other high-Arctic polythermal glaciers leads us to conclude that these ice masses may make a more significant contribution to global chemical-weathering budgets than previously assumed, since the rates are similar in magnitude to the continental average of $390 \mathrm{meq} \sum^{+} \mathrm{m}^{-2}$ year $^{-1}$ (Livingstone, 1963).

Discharge exerts a strong control on solute fluxes at Finsterwalderbreen, as illustrated by seasonal trends in
$\mathrm{HCO}_{3}{ }^{-}$loads and bulk runoff during 1994 and 1995 (Fig. 2b). The higher $\mathrm{HCO}_{3}{ }^{-}$loads in 1994 than in 1995 show that high discharges are accompanied by elevated solute fluxes. This supports conclusions reached in Alpine studies of chemical weathering rates and reflects the high flushing rates, turbulent meltwaters and high suspended-sediment concentrations which accompany high discharges (Sharp and others, 1995). These factors serve to promote chemical weathering by preventing the equilibration of meltwaters, providing large quantities of weatherable material and facilitating diffusion of $\mathrm{CO}_{2}$ into solution.

The strong interannual variability in chemical weathering rates at Finsterwalderbreen can also be ascribed to contrasting discharge conditions over the two melt seasons (Fig. 2a). A high incidence of intense rainfall events during the 1994 sampling season ( $\sim 79 \mathrm{~mm}$ ) was responsible for elevated discharges $\left(>35 \mathrm{~m}^{3} \mathrm{~s}^{-1}\right)$, producing a measured water flux of $4.1 \times 10^{7} \mathrm{~m}^{3}$. This compares with only $1.7 \times 10^{7} \mathrm{~m}^{3}$ in 1995 when rainfall receipts were $\sim 27 \mathrm{~mm}$ over the melt season and net incoming solar radiation exerted a stronger control on meltwater generation. It should be noted that these rainfall amounts were measured at sea level, and that precipitation at higher elevations in the catchment probably fell as snow and therefore did not contribute directly to runoff. Thus, meteorological conditions are an important determinant of chemical weathering rates via elevated discharge. High interannual variability in discharge, and hence chemical weathering rates, may be the norm on Spitsbergen glaciers (Repp, 1988). The 1994 and 1995 melt seasons represent extremes of rainfall conditions, the typical incidence of rainfall during summer in Spitsbergen lying intermediate between those recorded in 1994 and 1995 (unpublished information from Norsk Polarinstitutt, Oslo). Annual weathering rates of $440-210 \mathrm{meq} \sum^{+} \mathrm{m}^{-2}$ year ${ }^{-1}$ are, therefore, probably more common.

The incidence of elevated chemical weathering rates at Finsterwalderbreen, relative to cold-based glaciers, has im-

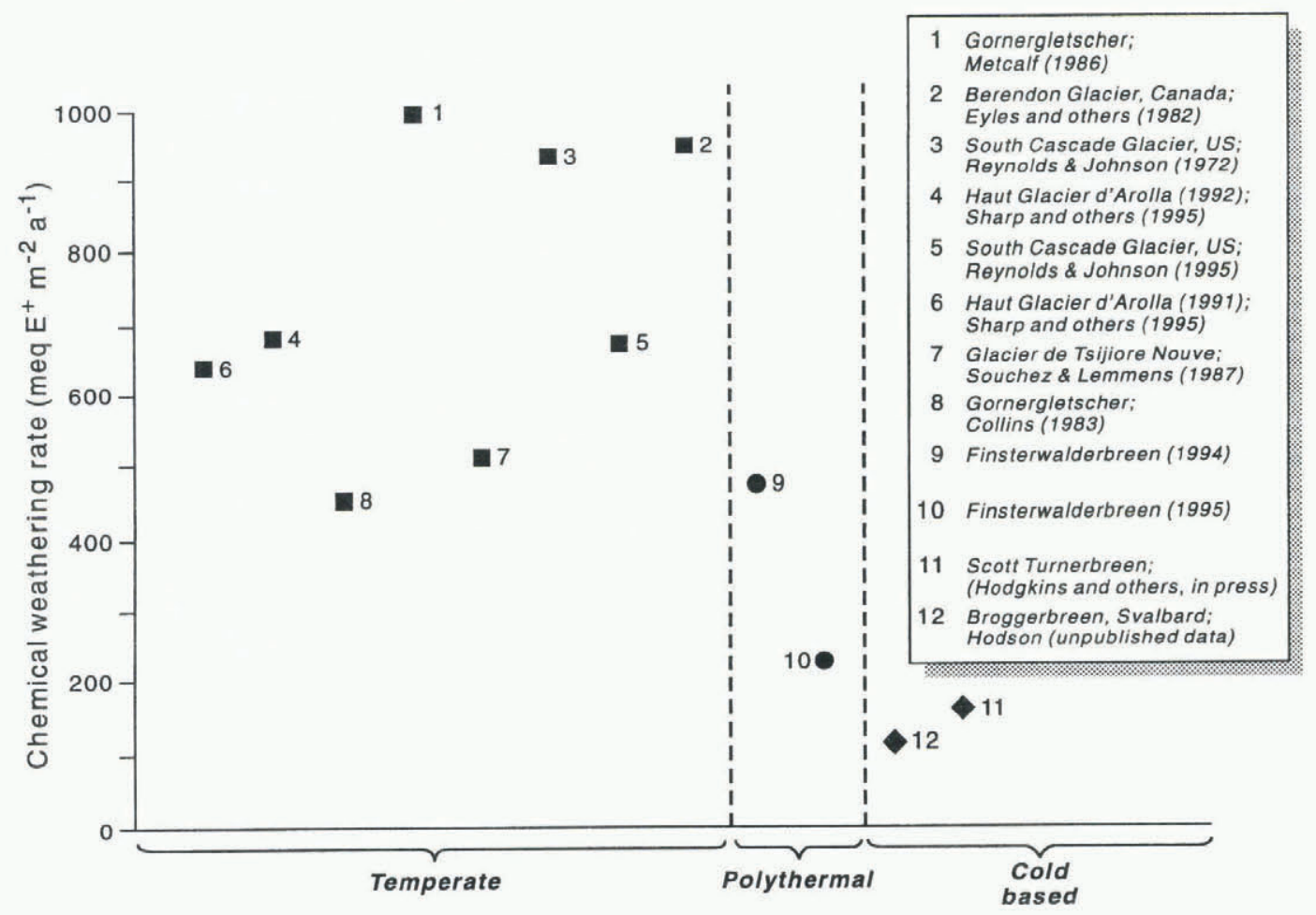

Fig. 4. Chemical weathering rates measured on glaciers of different thermal regime. 
plications for the drawdown of $\mathrm{CO}_{2}$ from the atmosphere. The steeper decline in ${ }^{*} \mathrm{SO}_{4}{ }^{2-}$ with discharge, relative to $\mathrm{HCO}_{3}$ (Fig. 3a), signifies an increasing dominance of carbonation reactions over sulphide oxidation as discharge rises, and an increased drawdown of $\mathrm{CO}_{2}$ into solution. This increased relative contribution of carbonation maintains high fluxes of cations, as is evident from the behaviour of $\mathrm{Ca}^{2+}$ concentrations as discharge rises (Fig. 3a). These features explain the strong, direct association of $\mathrm{CO}_{2}$ drawdown with discharge (Fig. 3b). The amount of $\mathrm{CO}_{2}$ drawdown per unit of discharge $\left(1.5 \mathrm{~g} \mathrm{C} \mathrm{m}^{-3}\right)$ is higher than that reported at Haut Glacier d'Arolla, a temperate glacier in Switzerland (Sharp and others, 1995). This demonstrates the potentially important role played by polythermal glaciers in the drawdown of $\mathrm{CO}_{2}$ from the atmosphere and the strong control of discharge on the magnitude of this removal. It is possible that periods of high meltwater production on longer time-scales, e.g. during deglaciation (Tranter, 1996) and the final stages of a surge, are accompanied by the removal of considerable volumes of $\mathrm{CO}_{2}$ from the atmosphere, provided meltwater is able to access weatherable rock material.

\section{GONGLUSIONS}

Chemical weathering rates at Finsterwalderbreen far exceed those measured on cold-based Arctic glaciers, and approach rates characteristic of temperate glacier systems. We consider thermal regime to be a first-order control on the magnitude of chemical weathering rates. A predominance of warm basal ice permits the development of a subglacial drainage system beneath Finsterwalderbreen, allowing surface meltwaters to access reactive basal material and acquire solute. Extrapolation of these findings to other large, polythermalbased, high-Arctic glaciers leads us to conclude that these ice masses have high chemical weathering potential, particularly during high-runoff years. This has implications for the drawdown of $\mathrm{CO}_{2}$ from the atmosphere at high discharges. The magnitude of $\mathrm{CO}_{2}$ drawdown per unit discharge at Finsterwalderbreen $\left(1.5 \mathrm{~g} \mathrm{C} \mathrm{m}^{-3}\right)$ is greater than that reported in the Alps $\left(1.2 \mathrm{~g} \mathrm{C} \mathrm{m}^{-3}\right.$; Sharp and others, 1995). We conclude that glacier basal thermal regime is an important determinant of chemical weathering rates through the degree of subglacial routing of water. Consequently, high-Arctic regions cannot be considered as areas of low chemical weathering rates and $\mathrm{CO}_{2}$ drawdown.

\section{ACKNOWLEDGEMENTS}

This work was supported by the Environment Programme grant EN5V-CT93-0299 to Prof. J. A. Dowdeswell and by U.K. Natural Environment Research Council (NERC) studentship GT4/94/116/A to J. L. Wadham. We thank Norsk Polarinstitutt, Oslo, for logistical support and J. Evans, I.
Frearson, D. Garbett, A. Jackson and W. Nandris for their assistance in the field.

\section{REFERENGES}

Collins, D. N. 1983. Solute yield from a glacierised high mountain basin. International Association of Hydrological Sciences Publication 141 (Symposium at Hamburg 1983 - Dissolved loads of rivers and surface water quantity/quality relationships), $41-49$.

Dallmann, W. K. and 7 others. 1990. Van Keulenfjorden. Oslo, Norsk Polarinstitutt. (Geological map, Svalbard Sheet BllG.)

Dowdeswell, J. A., D. J. Drewry, O. Liestøl and O. Orheim. 1984. Radio echo-sounding of Spitsbergen glaciers: problems in the interpretation of layer and bottom returns. F. Glaciol., 30(104), 16-21.

Eyles, N., D. R. Sasseville, R. M. Slatt and R. J. Rogerson. 1982. Geochemical denudation rates and solute transport mechanisms in a maritime temperate glacier basin. Can. 7. Earth Sci., 19(8), 1570-1581.

Gibbs, M.T. and L. R. Kump. 1994. Global chemical erosion during the Last Glacial Maximum and the present: sensitivity to changes in lithology and hydrology. Paleoceanography, 9(4), 529-543.

Hodgkins, R., M. Tranter and J. A. Dowdeswell. In press. Solute provenance, transport and denudation in a glacierised, high Arctic catchment. Hydrol. Processes.

Holland, H. D. 1978. The chemistry of the atmosphere and oceans. New York, etc., John Wiley and Sons.

Kump, L. R. and R. B. Alley. 1994. Global chemical weathering on glacial time scales. In Usselman, T. M. and W. W. Hay, eds. Material fluxes on the surface of the Earth. Washington, DC, National Academy Press. National Research Council. Geophysics Study Committee, 46-60. (Studies in Geophysics.)

Livingstone, D. A. 1963. Chemical composition of rivers and lakes. U.S. Geol. Surv. Prof. Pap. 400-G.

Metcalf, R. C. 1986. The cationic denudation rate of an Alpine glacial catchment. Z. Glelscherkd. Glazialgeol., 22(1), 19-32.

Nuttall, A. -M., J. O. Hagen and J. A. Dowdeswell, 1997. Quiescent-phase changes in velocity and geometry of Finsterwalderbreen, a surge-type glacier in Svalbard. Ann. Glaciol., 24 (see paper in this volume).

Ødegård, R. S., J. O. Hagen and S. -E. Hamran. 1997. Comparison of radioecho sounding $(30-1000 \mathrm{MHz})$ and high-resolution borehole-temperature measurements at Finsterwalderbreen, southern Spitsbergen, Svalbard. Ann. Glaciol., 24 (see paper in this volume).

Repp, K. 1988. The hydrology of Bayelva, Spitsbergen. Nord. Hydrol., 19 (4), 259-268.

Reynolds, R. C., Jr and N. M. Johnson. 1972. Chemical weathering in the temperate glacial environment of the Northern Cascade Mountains. Geochim. Cosmochim. Acta, 36(5), 537-554.

Schytt, V. 1969. Some comments on glacier surges in eastern Svalbard. Can. 7. Earth Sci., 6(4), Part 2, 867-873.

Sharp, M., M. Tranter, G. H. Brown and M. Skidmore. 1995. Rates of chemical denudation and $\mathrm{CO}_{2}$ draw-down in a glacier-covered Alpine catchment. Geology, 23 (1), $61-64$.

Souchez, R. A. and M. M. Lemmens. 1987. Solutes. In Gurnell, A.M. and M.J. Clark, eds. Glacio-fluvial sediment transfer: an Alpine perspective. Chichester, etc., John Wiley and Sons, 285-303.

Sugden, D. E. and B. S. John. 1976. Glaciers and landscape; a geomorphological approach. London, Edward Arnold.

Tranter, M. 1996. Glacial runoff as a sink for atmospheric $\mathrm{CO}_{2}$ during the last glacial/interglacial. In Bottrell, S., ed. Ath International Symposium on the Geochemistry of the Earth's Surface, 1996, Ilkley. Proceedings. Leeds, University of Leeds, 709-713.

Tranter, M., G. H. Brown, A. J. Hodson and A. M. Gurnell. 1996. Hydrochemistry as an indicator of subglacial drainage system structure: a comparison of Alpine and sub-polar environments. Hydrol. Processes, $10(4), 541-556$. 